\title{
Chromobacterium violaceum (Schröter 1872) ISOLATED FROM THE AQUATIC ENVIRONMENT ASSOCIATED WITH THE PSICULTURE OF JAÚ, Zungaro jahu (IHERING, 1898) (Siluriformes, Pimelodidae)
}

\author{
Chromobacterium violaceum (Schröter 1872) ISOLADO DE AMBIENTE AQUÁTICO \\ ASSOCIADO À PSICULTURA DE JAÚ, Zungaro jahu (IHERING, 1898) (Siluriformes, \\ Pimelodidae)
}

\begin{abstract}
Renato Ventresqui de OLIVEIRA ${ }^{1}$; Natália CONCEIÇÃO ${ }^{1}$; Douglas de Castro RIBEIRO ${ }^{\mathbf{1}}$; Fagner de SOUZA ${ }^{2}$; Maria das Graças REIS ${ }^{1}$; Marcelo Mattos PEDREIRA ${ }^{3}$; Paulo Roberto da SILVA ${ }^{1}$; Afonso PELLI ${ }^{1}$

1. Universidade Federal do Triângulo Mineiro, Instituto de Ciências Biológicas e Naturais, Departamento de Patologia, Genética e Evolução, Uberaba, Minas Gerais, Brasil. apelli@terra.com.br; 2. Universidade Estadual de Maringá, Programa de Pós-Graduação em Ecologia de Ambientes Aquáticos Continentais, Coleção Ictiológica do Núcleo de Pesquisas em Limnologia, Ictiologia e Aquicultura; 3. Universidade Federal do Vale do Jequitinhonha e Mucuri, Laboratório de Aquicultura e Ecologia Aquática, Diamantina, Minas Gerais, Brasil.
\end{abstract}

\begin{abstract}
The jau, Zungaro jahu (Ihering, 1898) is an endangered species, rheophilic, reaching $1.5 \mathrm{~m}$ and more than $100 \mathrm{~kg}$. During a work of microbiological monitoring of water quality, in the cultivation of Zungaro jahu, microorganisms that were isolated, were previously reported in other studies, as family members Enterobacteriaceae, Staphylococcus and non-fermenting bacilli. However, it was also isolated Chromobacterium violaceum, which despite being a bacterium found in such an environment, it was reported linked to the cultivation of fish. This paper describes the Chromobacterium violaceum founded in a psiculture, which has implications for national fish farming.
\end{abstract}

KEYWORDS: Fish farming. Pimelodidae. Siluriformes. Semi-intensive system. Water quality.

\section{INTRODUCTION}

Jaú, Zungaro jahu (Ihering, 1898), is a Siluriforme from the family Pimelodidae. An endangered reofílic species, it is native to the major rivers of the midwest, southeast, and southern regions of Brazil and is a predator that can reach 1.5 $\mathrm{m}$ and weigh more than $100 \mathrm{~kg}$ (PELLI et al, 2008; 2009).

Many native fish in the Neotropics have potential for fishing and recreation, such as piau, piapara, piracanjuba, golden fish, pacu, and tambaqui (BEDE et al, 1993; DUMONT NETO et al, 1997a; 1997b; PELLI et al, 1997a, 1997b). Despite having high reproductive capacities, many of these species are in the process of extinction due to the change in function or the destruction of their habitat, pollution, and dams (AGOSTINHO; ZALEWSKI, 1996), and especially due to the transformation of the great rivers into reservoirs and cascades (AMARAL et al, 2012;. PELLI et al, 2008; 2009).

The presence of microorganisms in farm fish can lead to the farm's economic losses because of possible infections; among the bacteria that can cause diseases in fish, Chromobacterium violaceum (Schröter 1872) is one of the important species.
Chromobacterium violaceum, belonging to Neisseriaceae family, is a gram-negative, facultative anaerobic, saprophyte microorganism that presents with the bacillus form, and a colony has 1 to $2 \mathrm{~mm}$ after growth at $30-35^{\circ} \mathrm{C}$ on blood agar (MURRAY et al., 2007). The main morphological characteristic is the presence of a violet pigment, known as 'violaceum', which gives a purple coloration to the colonies; however, unpigmented colonies have been described (SIVENDRA; TAN 1977). These microorganisms can also be recognized because they are oxidase-positive, glucose-fermenting, and lactose non-fermenting.

This microorganism can be found in different ecosystems in tropical and subtropical climates, normally inhabiting the soil and water in these regions (KOBURGER, MAY, 1982; HUNGRIA et al, 2005), and has already been described in Oreochromis niloticus (Linnaeus, 1758) cultivation systems (DAL PUPO, 2006).

Diseases due to the presence of $C$. violaceum were first reported in 1905 in Buffalo New York (WOOLEY, 1905). It is worth noting that infections in mammals are the most common, with reported cases in pigs (LIU et al., 1989) and dogs (GOGOLEWISKI, 1983). In 1956, it was reported that one of the first cases in humans occurred in 1927 in a newborn in Malaysia (SNEATH et al., 
1953). Infections in humans are rare, however, but when they occur, the mortality is high (MANJUNATH, 2007). Some studies have reported isolated cases in Brazil (MARTINEZ et al., 2000; DIAS et al, 2005) and abroad (LEE et al., 1999; TEOH et al., 2006).

The aim of this study was to report the characterization of $C$. violaceum when isolated in a Neotropical aquatic environment, in association with the cultivation of Jaú.

\section{COMMUNICATION}

Water samples were collected from Volta Grande farm fish in the municipality of Conceição das Alagoas, Minas Gerais, between the months of May and December 2009. Samples were collected randomly during the day in sterile flasks to avoid contamination of the samples.

The samples were plated on blood agar and MacConkey agar and incubated for 24-48 hours at $37^{\circ} \mathrm{C}$ as described by Murray et al. (2007)..

The morphology was evaluated using the Gram stain method. The microorganism identification was performed using the follow biochemical tests: catalase, urea, citrate, phenylalanine, $\mathrm{H}_{2} \mathrm{~S}$ production, indole, lysine, Voges Proskauer, Methyl Red, Bile-esculin, motility, arginine, ornithine, and TSI (triple sugar iron)..

Antimicrobial susceptibility was determined by disk diffusion test, as recommended by the Clinical and Laboratory Standards Institute - CLSI (2005), and the antimicrobials agents were: amikacin (30 mcg), ampicillin (10 g), cefoxitin (30 ug), ciprofloxacin (5ug), chloramphenicol (30 ug), gentamicin (10 ug), imipenem (10 g), nitrofurantoin $(300 \mathrm{ug})$, norfloxacin $(10 \mathrm{~g})$, piperacillin $(110 \mathrm{ug})$ and sulfazotrin $(25 \mathrm{~g})$.

A total of seven samples were taken, and at only three points in two different collections, the bacteria in question was isolated, which can probably be related to the biotic and abiotic parameters in the analyzed environments, such as the trophic level, ground proximity, and the occurrence of reservoir species.

The microorganism was identified as gramnegative bacilli with the Gram stain method. Through biochemical tests, it was shown to be an optional anaerobic and tested negative for urea, citrate, phenylalanine, $\mathrm{H} 2 \mathrm{~S}$ production, indole, lysine, Voges Proskauer, Methyl Red, and Bileesculin and positive for catalase, motility, arginine, and ornithine. The TSI showed an alkaline apex and an acid base.

In disk diffusion testing, the isolate was susceptible to amikacin, cefoxitin, ciprofloxacin, chloramphenicol, gentamicin, imipenem, nitrofurantoin, norfloxacin, and piperacillin sulfazotrin and had ampicillin resistance.

The results confirmed the isolate as the Chromobacterium violaceum. This is the first time that the occurrence of this species in a farm fish at Conceição das Alagoas, Minas Gerais, has been identified and has been related to the aquatic microbiota associated with the cultivation of Jau.

The authors suggest some hypotheses to justify these findings:

a) Exotic species such as $O$. niloticus could be incriminated as biological vectors;

b) The occurrence of natural reservoirs (meaning the habitat of an infectious agent, in which it lives, grows, and multiplies), such as mammals, could be these biological vectors; or

c) These species may have been introduced through urbanization with the consequent contamination of bodies and watercourses.

The finding is considered relevant because this environment is framed as Class 2 by CONAMA Resolution 357 (2005), which considers these enabling environments as well as the protection of aquatic communities, primary contact recreation, the irrigation of vegetables, aquaculture, and fishing activities; these activities involve direct contact with the aquatic environment and can put at significant risk the daily activities in these bodies of water, including those related to economic activities, such as aquaculture, bathing, recreation, and sport and commercial fishing.

\section{ACKNOWLEDGEMENTS}

The authors are grateful to the Support Foundation of the State of Minas Gerais Research (FAPEMIG) Education Foundation and Research Uberaba (FUNEPU), CAPES, CEMIG, Environmental Station of Volta Grande and the Federal University of Triângulo Mineiro by the facilities granted.

RESUMO: O jaú, Zungaro jahu (Ihering, 1898), é uma espécie em extinção, reofílica, atingindo 1,5 m e mais que $100 \mathrm{~kg}$. Durante um trabalho de monitoramento microbiológico da qualidade da água, no cultivo da espécie em foco, foram isolados microrganismos previamente descritos em outros estudos, como membros da família Enterobacteriaceae, 
Staphylococcus e bacilos não fermentadores. Além desses microrganismos, foi isolada também a espécie Chromobacterium violaceum, que apesar de ser uma bactéria encontrada neste tipo de ambiente, não foi relatada associada ao cultivo de peixes. Este trabalho relata este importante achado, que pode trazer implicações à piscicultura nacional.

PALAVRAS-CHAVE: Pimelodidae. Piscicultura. Qualidade de água. Sistema semi-intensivo. Siluriformes.

\section{REFERENCES}

Agostinho, A. A.; ZALEWSKI, M. A planície alagável do alto Rio Paraná: importância e preservação. Maringá: Eduem, 1996. 100 p.

AMARAL, M. V. C.; PEDREIRA, M. M.; COSTA, D. C.; DUPIM, A. E.; PELLI, A.; OLIVEIRA, N. M. Time of feed transition and inclusion levels of exogenous protease in rations for piabanha-do-Pardo Brycon sp. hatchery. Acta Scientiarum. Zootechny, Maringá, v. 34, p. 347-353, 2012.

BEDE, L. C.; SANTOS, G. B.; ALVES, C. B. M.; PELLI, A. Alimentação de peixes do reservatório da Pampulha, Belo Horizonte, MG, com ênfase na malacofagia. Revista Ceres, Viçosa, v. 40, p. 429-437, 1993.

CONAMA. Resolução No 357, de 17 de março de março de 2005, do Conselho Nacional do Meio Ambiente do Ministério do Meio Ambiente. Brasília/DF, Disponível em:

http://www.mma.gov.br/port/conama/res/res05/res35705.pdf. Acesso em: 10 ago. 2010.

DAL PUPO, H. D. Diversidade da microbiota Gram-negativa em sistemas de cultivo de Tilápia-do-Nilo (Oreochromis niloticus). 2006. 42 f. Dissertação (Mestrado em Ciências Veterinárias) - Universidade Federal de Lavras, Lavras.

DIAS, J. P.; SILVANY, C.; SARAIVA, M. M.; RUF, H. R.; GUZMAN, J. D.; CARMO, E. H. Chromobacteriosis in Ilhéus, Bahia: epidemiologic, clinical and laboratorial investigation. Revista da Sociedade Brasileira de Medicina Tropical, Uberaba, v. 38, p. 503-506, 2005.

DUMONT NETO, R.; PELLI, A.; FREITAS, J. L.; COSTA, C. L.; FREITAS, A. E.; BARBOSA, N. D. C. Reprodução induzida da piracanjuba (Brycon orbignyanus, Valenciennes, 1903) durante a primeira maturação sexual, cultivada em cativeiro, na estação de pesquisa e desenvolvimento ambiental de Volta Grande - CEMIG.

Boletim do Instituto de Pesca, São Paulo, v. 24, p. 105-107, 1997a.

DUMONT NETO, R.; PELLI, A.; FREITAS, J. L.; COSTA, C. L.; FREITAS, A. E.; BARBOSA, N. D. C. Reprodução induzida do dourado (Salminus maxillosus Valenciennes, 1849), na estação de pesquisa e desenvolvimento ambiental de Volta Grande - CEMIG/EPDA-VG, período novembro/1994 a janeiro/1995. Revista Unimar, Maringá, v. 19, p. 439-445, 1997 b.

GOGOLEWISKI, R. P. Chromobacterium violaceum septicaemia in a dog. Australian Veterinary Journal, St Leonards, v. 60, p. 226, 1983.

HUNGRIA, M.; ASTOLFI-FILHO, S.; CHUEIRE, L. M. O.; NICOLÁS, M. F.; SANTOS, E. B. P.; BULBOL, M. R.; SOUZA-FILHO, A.; ASSUNÇÃO, E. N.; GERMANO, M. G.; VASCONCELOS, A. T. R. Genetic characterization of Chromobacterium isolates from black water enviroments in the Brazilian Amazon. Letters in Applied Microbiology, Cardiff, v. 41, p. 17-23, 2005.

KOBURGER, J. A.; MAY, S. O. Isolation of Chromobacterium spp. from foods, soil, and water. Applied and Environmental Microbiology, Washington, v. 44, p. 1463-1465, 1982.

LEE, J.; KIM, J. S.; NAHM, C. H.; CHOI, J. W.; KIM, J.; PAI, S. H.; MOON, K. H.; LEE, K.; CHONG, Y. Two cases of Chromobacterium violaceum infection after injury in a Subtropical Region. Journal of Clinical Microbiology, Washington, v. 37, p. 2068-2070, 1999. 
LIU, C. H.; CHU, R. M.; WING, C. N.; LIN, Y. L.; CHI, C. S. An acute pleuropneumonia in a pig caused by Chromobacterium violaceum. Journal of Comparative Pathology, Athens, v. 100, p. 459-463, 1989.

MANJUNATH, M. Fatal septicaemia due to Chromobacterium violaceum. West Indian Medical Journal, Mona, v. 56, p. 380-381, 2007.

MARTINEZ, R.; VELLUDO, M. A. S. L.; SANTOS, V. R.; DINAMARCO, P. V. Chromobacterium violaceum infection in Brazil. A case report. Revista do Instituto de Medicina Tropical de São Paulo, Uberaba, v. 42, p. 111-113, 2000.

MURRAY, B. E.; BARON, E. J.; JORGENSEN, J. H.; LANDRY, M. L.; PFALLER, M. A. Manual of Clinical Microbiology. 9 ed. Washington: ASM Press, 2007. 2256 p.

PELLI, A.; ARRUDA, A. A. M.; SILVA, L. E.; LOPES, J. M.; COSTA, C. L.; BEDORE, A. G.; REZENDE, A. P. S.; GODINHO, H. P. Efeito da densidade de estocagem sobre a sobrevivência de alevinos de jaú, Zungaro jahu (Ihering, 1898) em tanques de cultivo semi-intensivo. Revista Brasileira de Zoociências, Juiz de Fora, v. 11, p. 7-9, 2009.

PELLI, A.; DUMONT NETO, R.; SILVA, J. D.; GONÇALVES, S. M. R.; SOUZA, D. S.; BARBOSA, N. D. C. Ingestão de ração por pacu (Piaractus mesopotamicus Holmberg, 1887), curimba (Prochilodus scrofa Steindachner, 1881) e piau (Leporinus friderici Bloch, 1794) em condições semi intensivas. Boletim do Instituto de Pesca, São Paulo, v. 24, p. 119-123, 1997a.

PELLI, A.; DUMONT NETO, R.; SILVA, J. D.; GONÇALVES, S. M. R.; SOUZA, D. S.; BARBOSA, N. D. C. Observações sobre o hábito alimentar de dourado (Salminus maxillosus Valenciennes, 1849) em condições de criação semi-intensivo e em laboratório. Revista Unimar, Maringá, v. 19, p. 509-520, 1997b.

PELLI, A.; PAULA, D. R.; ARRUDA, A. A. M.; LOPES, J. M.; RAMOS, S. M.; REZENDE, A. P. S. Toxicidade aguda e crônica de diflubenzuron para o jaú, Zungaro zungaro (Humboldt, 1821) (Pisces, Pimelodidae). Revista Brasileira de Zoociências, Juiz de Fora, v. 10, p. 51-54, 2008.

SIVENDRA, R.; TAN, S. H. Pathogenicity of nonpigmented cultures of Chromobacterium violaceum. Journal of Clinical Microbiology, Washington, v. 5, p. 514-516, 1977.

SNEATH, P. H. A.; WHELAN, J. P. F.; SINGH, R. B.; EDWARDS, D. Fatal infection by Chromobacterium violaceum. Lancet, London, v. 2, p. 276-277, 1953.

TEOH, A. Y. B.; HUI, M.; NGO, K. Y.; WONG, J.; LEE, K. F.; LAI, P. B. S. Fatal septicaemia from Chromobacterium violaceum: case reports and review of the literature. Hong Kong Medical Journal, Hong Kong, v. 12, p. 228-231, 2006.

WOOLEY, P. G. Bacillus violaceum manilae (a pathogenic organism). Bulletin of the Johns Hopkins Hospital, Baltimore, v. 16, p. 89, 1905. 